\title{
The influence of polyethylene glycol inclusion in Vachellia tortilis leaf meal on nitrogen balance in growing pigs
}

\author{
V.A. Hlatini, T.J. Zindove \& M. Chimonyo\# \\ Animal and Poultry Science, School of Agricultural, Earth and Environmental Sciences, \\ University of KwaZulu-Natal, P/Bag X 01 Scottsville 3209, Pietermaritzburg, South Africa
}

(13 January 2017; Accepted 4 March 2017; First published online 3 April 2017)

\begin{abstract}
Copyright resides with the authors in terms of the Creative Commons Attribution 4.0 South African Licence.
See: http://creativecommons.org/licenses/by/4.0/za

Condition of use: The user may copy, distribute, transmit and adapt the work, but must recognise the authors and the South African Journal of Animal Science.
\end{abstract}

\begin{abstract}
The incorporation of polyethylene glycol (PEG), a tannin binding agent, in high tannin feedstuff is known to prevent tannin-protein complexes. Environmental contamination with nitrogen-containing products in manure is a topical issue in the tropics. The objective of the study was to determine the extent to which the incorporation of PEG in Vachellia tortilis leaf meal improved nitrogen balance, serum iron, and phosphorus in growing pigs. Forty-eight clinically healthy male PIC pigs $(31.3 \pm 1.28 \mathrm{~kg}$; Landrace $\mathrm{x}$ Large White) were allotted to individual pens in a completely randomized design, with eight pigs per treatment. They were offered a diet that contained $150 \mathrm{~g} \mathrm{~V}$. tortilis/kg dry matter (DM). The diets were treated with $0,5,10,15,20$, and $25 \mathrm{~g} \mathrm{PEG} / \mathrm{kg}$. As PEG inclusion increased, serum iron concentration also rose until it reached a plateau. Nitrogen $(\mathrm{N})$ utilisation and retention significantly increased linearly with PEG inclusion. Nitrogen excretion through faeces and urine significantly decreased linearly when increasing the amount of PEG in $V$. tortilis leaf meal in feed offered to pigs. Nitrogen utilization significantly increased linearly as the inclusion of PEG rose. It can be concluded that the inclusion of PEG increased $\mathrm{N}$ balance.
\end{abstract}

Keywords: average daily gain, nitrogen intake, nitrogen retention, phytate, polyphenolic compounds

\#Corresponding author: Chimonyo@ukzn.ac.za

\section{Introduction}

The use of leaf meals from indigenous legume trees and shrubs as livestock feed is gaining popularity in tropical countries (Woyengo et al., 2014). Leaf meals provide inexpensive, locally available crude protein, minerals, and energy, leading to reduced cost of production. The use of leaf meals in feeding pigs reduces competition for grains with human beings and bio-energy production. Vachellia tortilis, formerly known as Acacia tortilis leaf meal, has the potential to become a reliable protein source in the tropics and sub-tropics (Martens et al., 2013; Woyengo et al., 2014). The use of V. tortilis, however, is limited largely by the presence of polyphenolic compounds, thorns, and high fibre content (Bhat et al., 2013; Lindberg, 2014; Lalthansanga \& Samanta, 2015). While thorns can be removed mechanically through sieving, the polyphenolic compounds are still a major drawback to the use of leguminous plants to feed pigs. At high inclusion levels, polyphenolic compounds cause an astringent taste to pigs (Khanyile et al., 2014). They form insoluble complexes with divalent metal ions, such as iron, reducing its bioavailability in legume feeds (Štukelj et al., 2010). Phosphorus affects protein synthesis, growth, and feed conversion rate (FCR). Most of the phosphorus, however, is bound to phytic acid in $V$. tortilis and is therefore not available to pigs.

When PEG is incorporated in a high tannin leaf meal diet, it has been shown to increase feed intake and growth performance in pigs (Bhat et al., 2013; Hlatini et al., 2016). It reduces astringency, and increases appetite and palatability of tanniferous forages. The PEG binds with tannins and it releases the proteins from the complex. However, there is little, if any, information about the effect of treating tanniferous diets with PEG on nitrogen $(\mathrm{N})$ retention. Modern pig production faces the dual challenges of producing pork efficiently and avoiding environmental contamination with waste products, especially $\mathrm{N}$-containing products in manure (Patrás et al., 2014). There is a need to determine the influence of treating tanniferous diets with PEG on N retention and excretion. The objective of the study was therefore to determine the effect of PEG-treated $V$. tortilis leaf meal-based diet on $\mathrm{N}$ balance in growing pigs. It was hypothesized that $\mathrm{N}$ balance would be improved linearly with PEG inclusion. 


\section{Materials and Methods}

The study was conducted at Ukulinga Research Farm at the University of KwaZulu-Natal, Pietermaritzburg, South Africa. Ethical approval for the experiment was granted by the UKZN Animal Ethics Committee (reference number 076/14/Animal). Forty-eight clinically healthy male pig improvement group (PIC) pigs were randomly allotted to individual pens. The pigs were housed in a room with artificial heating, lighting, and proper ventilation systems. The ambient temperature and relative humidity were recorded throughout the experiment at 15-minute intervals using a HOBO Temperature, $\mathrm{RH}^{\odot}, 1996$ ONSET logger (Onset Computer Corporation). The pig house was maintained at a temperature of $21.9 \pm 2.24{ }^{\circ} \mathrm{C}, 45.2 \pm$ $6.85 \%$ relative humidity and a 12-h dark-12-h artificial light cycle. The pigs were not given antibiotics or growth promoters. The measurement of performance parameters was done weekly between $0700 \mathrm{~h}$ and $0830 \mathrm{~h}$, then average daily bodyweight gain (ADG) was measured by taking the difference between the bodyweight (BW) at the beginning and end of each week and dividing it by seven. The feed conversion ratio was determined through dividing feed intake by ADG.

Vachellia tortilis leaves were harvested at Makhathini Research Station, Jozini, South Africa. Located at an altitude of $77 \mathrm{~m}$ above sea level, it has a mean minimum and maximum daily temperature of $7{ }^{\circ} \mathrm{C}$ and $35{ }^{\circ} \mathrm{C}$, respectively. The leaves were harvested during the post rainy season at an advanced stage of maturity. Harvesting to obtain the targeted mass occurred between February and April in 2014. Tree branches were clipped from the growing points and air-dried for three days in the shade to prevent damage to heat-sensitive nutrients. Polyethylene sheets were used during drying to prevent contamination with soil. During drying, leaf meals were often turned to prevent the accumulation of moulds. The branches were then careful beaten with sticks to release the leaves. To remove thorns and pods, leaves were passed through a 2-mm sieve, bagged and kept in a well-ventilated dry room until required for dietary formulation.

The pigs were fed on each diet for 36 days, with eight pigs per treatment. Pigs weighing about 31.3 (s.d. $=1.28) \mathrm{kg}$ were individually penned and randomly allocated to each of the six treatments. The size for each pen was $1.5 \times 1 \mathrm{~m}^{2}$. Each pen was provided with water through low-pressure nipple drinkers and feed was supplied in a plastic self-feeder trough (Big Dutchman Lean Machine ${ }^{\circledR}$, Postfach). The PEG, with a molecular weight of 4000 was supplied by Old Mill Industrial Park, Durban, South Africa. The PEG was added on top of the basal diet prior to being mixed thoroughly with a feed mixer. Diets contained $150 \mathrm{~g} \mathrm{~V}$. tortilis/kg (DM basis) and treated with 0, 5, 10, 15, 20, and $25 \mathrm{~g} \mathrm{PEG} / \mathrm{kg}$. The basal diet used in diet formulation was prepared to meet the target for growing pigs, which ranges between 180 and $220 \mathrm{~g} / \mathrm{kg} \mathrm{DM}$ (NRC, 2012). The diets were formulated to be iso-nitrogenous and iso-energetic. Table 1 shows the ingredient composition of the basal diet. Feed and water were provided ad libitum.

Table 1 Ingredient composition of the diet used in the study

\begin{tabular}{lc}
\hline Ingredient & DM basis $\mathbf{( g / \mathbf { k g } )}$ \\
\hline Vachellia tortilis leaf meal & 150.0 \\
Maize & 345.8 \\
Wheat bran & 194.0 \\
Soybean meal & 220.1 \\
Oil-Sunflower & 50.0 \\
Limestone & 17.6 \\
Monocalcium phosphate & 13.3 \\
Sodium chloride & 3.3 \\
L-Lysine HCL & 2.0 \\
Vitamin-mineral premix & 1.5 \\
DL- Methionine & 1.4 \\
L-Threonine & 0.9 \\
\hline
\end{tabular}

Dry matter, ash, crude protein, and ether extract of the diets were determined using standard AOAC methods. Nitrogen content were analysed following Dumas combustion method in a Leco Truspec nitrogen analyser, St Joseph Mi, USA. A factor of 6.25 was used to calculate CP content. The neutral detergent fibre 
(NDF) and acid detergent fibre (ADF) were determined using Ankom Fiber Analyser (Ankom Macedon, NY, USA) following methods by Van Soest et al. (1991). Acid hydrolyses were used for amino acid preparation before analyses using an amino acid analyser (SY-KAM, Erising, Germany). Proanthocyanidin concentration was determined calorimetrically according to the butanol-HCL method (Reed, 1986). Water holding and swelling capacity were determined according to methods described by Whittemore et al. (2003). Samples for minerals were ashed at $450{ }^{\circ} \mathrm{C}$ and dissolved in $1 \mathrm{M} \mathrm{HCl}$ (Abdou et al., 2011). Mineral contents were detected with a Varian 720 inductively coupled plasma emission spectrometer (Frankfurt, Germany) using atomic absorption. Ten millilitres blood was collected from the jugular vein with vacutainer tubes containing sodium heparin as the anticoagulant (Becton Dickinson, Franklin, NJ). Then samples were centrifuged at $1000 \times \mathrm{g} 10 \mathrm{~min}$ at $25^{\circ} \mathrm{C}$ (within two hours of collection) prior being kept at $-20^{\circ} \mathrm{C}$ until analysis. The serum metabolites analysed were iron and phosphorus. Metabolites were measured spectrophotometrically with an automated chemistry analyser, using kits from Labtest Diagnostics (Labmax Plenno, Labtest, Lagoa-Santa, Brazil). Tables 2 and 3 show the chemical analysis of and nutrient composition of $V$. tortilis leaf meal-based diets, respectively.

Table 2 Chemical analysis of Vachellia tortilis leaves and diet

\begin{tabular}{|c|c|c|}
\hline Component & Leaf meal & Diet \\
\hline Dry matter $(\mathrm{g} / \mathrm{kg})$ & 992 & 894 \\
\hline Gross energy (MJ/kg) & 17.7 & 17.5 \\
\hline Ash (g/kg DM) & 65.1 & 72.2 \\
\hline Crude protein (g/kg DM) & 218.4 & 215.2 \\
\hline Ether extract (g/kg DM) & 40.2 & 86.4 \\
\hline Nitrogen free extract (g/kg DM) & ND & 521.7 \\
\hline Neutral detergent fibre (g/k DM) & 495 & 241.2 \\
\hline Acid detergent fibre (g/kg DM) & 298.6 & 104.2 \\
\hline Neutral detergent insoluble nitrogen (g/kg DM) & 27.5 & 22.8 \\
\hline Acid detergent insoluble nitrogen ( $\mathrm{g} / \mathrm{kg} \mathrm{DM}$ ) & 18.3 & 14.9 \\
\hline Condensed tannins (mg/kg DM) & 51.6 & 7.7 \\
\hline Fat $(g / k g ~ D M)$ & ND & 84.1 \\
\hline Nitrogen free extract \% & ND & 52.4 \\
\hline
\end{tabular}

DM: dry matter; ND: not determined

The trial for the total collection of faeces and urine lasted for five days from day 32 to day 36 . Urine and faecal measurements were done each morning at 08h00, for five consecutive days. The hand-picking method was practised to completely collect faeces from the pens and place them in plastic bags. Faeces were collected over a 24-hour period from the edges of the pen and a 1-mm sieve was suspended underneath each pen to capture faeces that fell out (Ouellet et al., 2004). At the end of total collection period, the faecal samples were mixed thoroughly, weighed, sub-sampled $(250 \mathrm{~g})$, and dried at $60{ }^{\circ} \mathrm{C}(1 \%$ formalin being used for conservation) pending analysis. Plastic trays were positioned below pens to allow for the total collection of urine that would have oozed through the 1-mm sieve (above). Urine was removed every day, weighed, and placed in a clean container. To reduce the volatilization of nitrogenous compounds in the urine, $2 \mathrm{ml} 25 \%$ sulphuric acid was added to each tray within five minutes of collection. After weighing the total urine, $250 \mathrm{ml}$ of urine was sampled for analyses. Collected faeces and urine samples were stored at $4{ }^{\circ} \mathrm{C}$ pending analyses. The $\mathrm{N}$ content level of faeces and urine were determined according to the Kjeldahl procedure (AOAC, 1990). The following equations were used to determine $\mathrm{N}$ retention, $\mathrm{N}$ digestibility, $\mathrm{N}$ retained and $\mathrm{N}$ utilization:

$\mathrm{N}$ retention $(\mathrm{g})=$ Ingested $\mathrm{N}(\mathrm{NI})(\mathrm{g})-($ faecal $\mathrm{N}$ output $(\mathrm{FNO})+$ urinary $\mathrm{N}$ output $(\mathrm{UNO})(\mathrm{g})$

$\mathrm{N}$ retention $\%=\mathrm{NI}(\mathrm{g})-(\mathrm{FNO}+\mathrm{NU})(\mathrm{g}) / \mathrm{NI}(\mathrm{g}) \times 100$

Digested $\mathrm{N}(\mathrm{g})=\mathrm{NI}(\mathrm{g})-\mathrm{FNO}(\mathrm{g})$

$\mathrm{N}$ digestibility $\%=((\mathrm{NI}-\mathrm{FNO}) / \mathrm{NI}) \times 100$

Retained nitrogen $(\mathrm{RN})(\mathrm{g})=\mathrm{N} \operatorname{dig}(\mathrm{g})-\mathrm{UNO}(\mathrm{g})$ 
$\mathrm{N}$ utilization $(\mathrm{NU}) \%=(\mathrm{RN} / \mathrm{NI}) \times 100$

Where: $\mathrm{NFO}=$ faecal $\mathrm{N}$ output,

$\mathrm{UNO}=$ urine $\mathrm{N}$ output

Total $\mathrm{N}$ excretion $=\mathrm{FNO}+\mathrm{UNO}$

Net protein utilization $=\mathrm{NR} / \mathrm{NI}$

Biological value of feed protein $(B V F P)=N R / N D$

Table 3 Amino acid and mineral composition of Vachellia tortilis leaf meal-based diet

\begin{tabular}{|c|c|}
\hline Component & Diet \\
\hline Cystine (g/100g DM) & 4.92 \\
\hline Methionine (g/100g DM) & 3.13 \\
\hline Tyrosine (g/100g DM) & 6.78 \\
\hline Histidine (g/100g DM) & 9.82 \\
\hline Lysine (g/100g DM) & 9.80 \\
\hline Threonine (g/100g DM) & 6.25 \\
\hline Phenylalanine ( $g / 100 \mathrm{~g} D M)$ & 8.24 \\
\hline Valine (g/100 g DM) & 9.81 \\
\hline Sodium (g/kg ) & 12.8 \\
\hline Copper (mg/kg) & 7.89 \\
\hline Magnesium ( g/kg ) & 2.54 \\
\hline Manganese (mg/kg) & 127 \\
\hline Potassium (g/kg) & 10.9 \\
\hline Calcium (g/kg DM) & 12.1 \\
\hline Phosphorus (g/kg DM) & 7.90 \\
\hline Zinc (mg/kg) & 80.9 \\
\hline Iron (mg/kg) & 250.0 \\
\hline
\end{tabular}

The data were analysed using the response surface regression procedure (SAS, 2008) to determine the relationship between PEG inclusion levels and nitrogen balance. The initial BWs of pigs were included in the model as a covariate. The PROC MIXED procedure of Statistical Analysis Systems Institute was used to analyse the inclusion level of PEG and week on pig growth (BWT, ADG and FCR) to consider repeated measures done every week. The separation of means was done with PDIFF option.

The regression model used was:

$$
Y=\beta_{0}+\beta_{1} L+\beta_{2} L^{2}+E
$$

Where: $Y$ is the response variables (BWT, ADG, FCR, iron, phosphorous, $N$ retention, $N$ digestibility, urinary $N$, faecal $N, N$ intake and urinary $N$ : faecal $N$ ratio), $\beta_{0}+\beta_{1}+\beta_{2}$ regression coefficients, $L$ is the PEG inclusion level, $\mathrm{E}$ is the residual error.

\section{Results}

Table 4 shows the effect of $V$. tortilis meal treated with incremental levels of PEG on feed intake, BWG and feed conversion ratio. Incorporated as a covariate, the initial BW had no effect on nitrogen balance, growth performance and nitrogen balance of pigs. The increasing amount of PEG in $V$. tortilis leaf meal affected BW response of pigs $(P<0.01)$. There was a linear increase in ADG with PEG inclusion $(P<0.01)$. However, there was, no relationship between PEG inclusion and FCR $(P>0.05)$.

Inclusion of PEG had a quadratic response in iron $(\mathrm{Fe})$ concentration $(P<0.01)$. As the PEG inclusion level increased, the serum Fe increased initially then started to decrease (Figure 1). The PEG inclusion did not influence serum phosphorus concentration $(P>0.05)$. 
Table 4 Mean final body weight, average daily gain and feed conversion ratio of pigs $(n=48)$ fed on increasing levels of PEG into Vachellia tortilis leaf meal-based diet

\begin{tabular}{|c|c|c|c|c|c|c|c|c|c|c|}
\hline \multirow{2}{*}{ Parameter } & \multicolumn{6}{|c|}{ Inclusion level of PEG (g/kg DM) } & \multirow{2}{*}{ SEM } & \multicolumn{2}{|c|}{$\begin{array}{c}\text { Regression } \\
\text { Coefficient }\end{array}$} & \multirow{2}{*}{ Sig } \\
\hline & 0 & 5 & 10 & 15 & 20 & 25 & & Linear & quadratic & \\
\hline Final body weight $(\mathrm{kg})$ & 30.80 & 30.88 & 30.79 & 29.83 & 30.86 & 33.55 & 0.630 & & & * \\
\hline ADG (kg/day) & 0.65 & 0.58 & 0.65 & 0.74 & 0.69 & 0.78 & 0.024 & -0004 & 0.001 & \\
\hline FCR ( $k$ feed/kg gain) & 1.85 & 1.94 & 1.97 & 2.08 & 2.04 & 1.98 & 0.085 & & & NS \\
\hline
\end{tabular}

${ }^{*} P<0.05$; NS: not significant $(P>0.05)$.

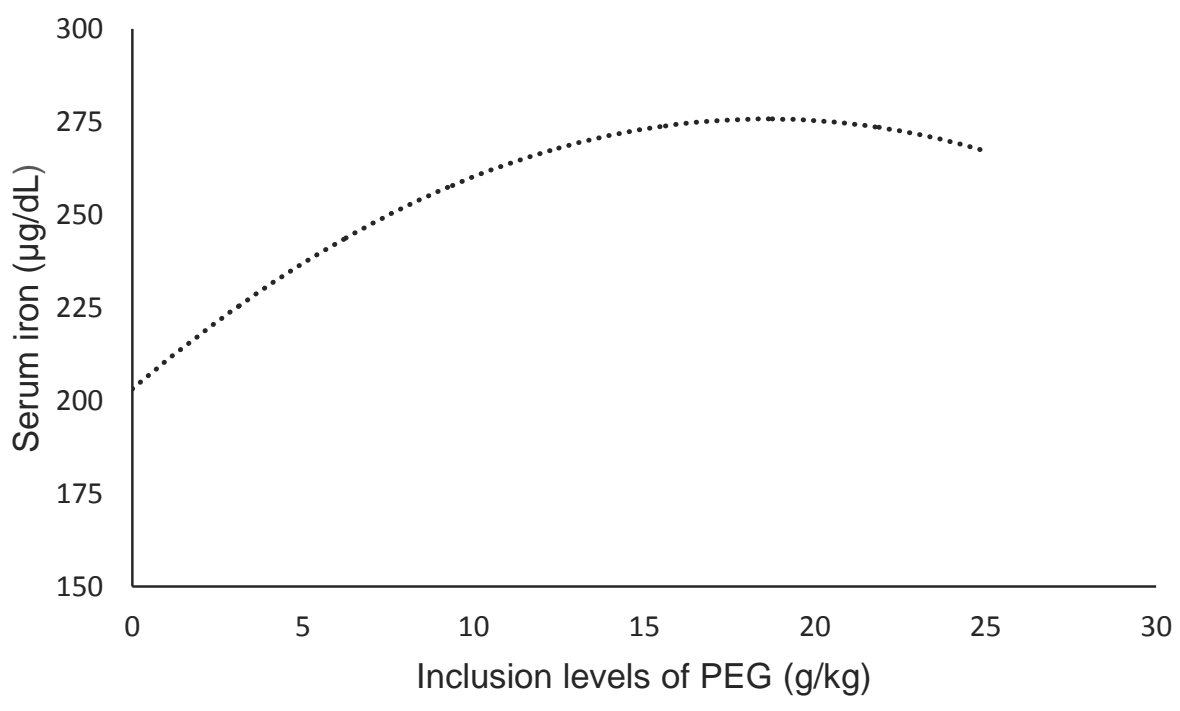

Figure 1 Relationship of polyethylene glycol in Vachellia tortilis leaf meal diet and serum iron concentrations Serum iron concentration is predicted as $Y=203.2+7.81 \times-0.21 \mathrm{x}^{2}(P<0.05)$

The influence of PEG inclusion in $V$. tortilis leaf meal-based diets on $\mathrm{N}$ balance is shown in Table 5 . The response of $\mathrm{NI}, \mathrm{NR}, \mathrm{NU}$ and urine $\mathrm{N}$ excretion : faecal $\mathrm{N}$ excretion (UN : FN) to PEG incorporation into $V$. tortilis leaf meal is shown in Figure 2. Nitrogen intake (NI) responded quadratically to PEG inclusion level $(P<0.01)$. As $\mathrm{PEG}$ inclusion increased, the $\mathrm{NI}$ decreased initially and then started to increase (Figure 2a). A negative linear relationship between urine $\mathrm{N}$ output (UNO) and PEG inclusion was observed $(P<0.05)$. The nitrogen faecal output (NFO) had a decreasing quadratic response to PEG inclusion $(P<0.01)$, NFO decreased initially and then increased with PEG inclusion. The total $N$ excreted responded linearly to PEG inclusion $(P<0.01)$. Excreted $\mathrm{N}$ decreased with increasing levels of PEG. As the inclusion level of PEG increased. Although faecal $\mathrm{N}$ content decreased with $V$. tortilis inclusion, the rate of decrease was only half that of urinary N. $(P<0.05)$.

There was a linear relationship between apparent nitrogen digestibility \% and PEG inclusion $(P<0.01)$. Nitrogen digestibility increased with PEG inclusion. Nitrogen retention (NR) (g) responded linearly to PEG inclusion levels $(P<0.01)$. Nitrogen retention decreased initially and then increased with $P E G$ inclusion (Figure $2 b$ ). Inclusion of PEG in $V$. tortilis leaf meal showed a positive quadratic relationship with nitrogen retained in percentage $(P<0.01)$. The nitrogen retained increased with level of $P E G$ at an increasing rate. Nitrogen utilized (NU) had a positive linear response to PEG inclusion $(P<0.01$; Figure $2 \mathrm{c})$. The net protein utilisation (NPU) had a linear relationship with inclusion levels of PEG $(P<0.05)$. 
Table 5 Influence of polyethylene glycol level in Vachellia tortilis leaf meal-based diet on nitrogen balance in pigs $(n=48)$

\begin{tabular}{|c|c|c|c|c|c|c|c|c|c|c|}
\hline & \multicolumn{6}{|c|}{$\begin{array}{c}\text { Inclusion level of polyethylene glycol in Acacia tortilis leaf } \\
\text { meal-based diet }\end{array}$} & \multirow[t]{2}{*}{ SEM } & \multicolumn{2}{|c|}{$\begin{array}{c}\text { Regression } \\
\text { coefficient }\end{array}$} & \multirow[t]{2}{*}{ Sig } \\
\hline & 0 & 5 & 10 & 15 & 20 & 25 & & Quadratic & Linear & \\
\hline Urinary N (g/day) & 13.0 & 10.4 & 10.4 & 9.60 & 7.33 & 5.02 & 4.50 & & -2.0 & * \\
\hline Faecal N (g/day) & 28.1 & 21.1 & 24.2 & 25.1 & 22.7 & 18.7 & 1.92 & 0.02 & -1.02 & * \\
\hline $\begin{array}{l}\text { Total N excretion } \\
\text { (g/day) }\end{array}$ & 41.1 & 31.5 & 33.8 & 35.5 & 30.0 & 23.7 & 4.33 & & -2.55 & * \\
\hline Digested N \% & 42.5 & 44.4 & 41.8 & 55.5 & 59.7 & 57.2 & 4.47 & & 2.0 & $* *$ \\
\hline $\mathrm{N}$ retention \% & 42.3 & 42.7 & 41.7 & 45.1 & 46.5 & 53.0 & 0.001 & 0.03 & -0.34 & $* * *$ \\
\hline NPU \% & -35.1 & 21.6 & 20.2 & 29.8 & 50.4 & 43.3 & 10.4 & & 0.05 & * \\
\hline BVFP \% & -14.5 & 43.4 & 26.8 & 54.4 & 83.2 & 75.2 & 4.78 & & & NS \\
\hline $\begin{array}{l}\text { Phosphorus } \\
\text { (mg/dl) }\end{array}$ & 10.8 & 10.3 & 10.9 & 10.3 & 8.8 & 10.4 & 0.23 & & & NS \\
\hline
\end{tabular}

SEM: standard error of mean; NS: not significant; ${ }^{*} P<0.05$; ${ }^{* \star} P<0.01$; Sig: significance level; N: nitrogen NPU: net protein utilisation; BVFP: Biological value of feed protein.

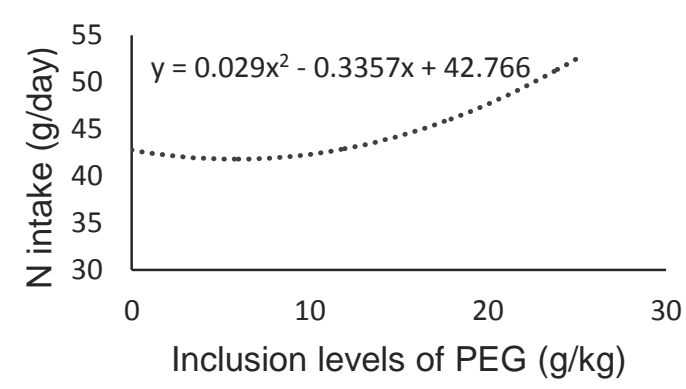

a)

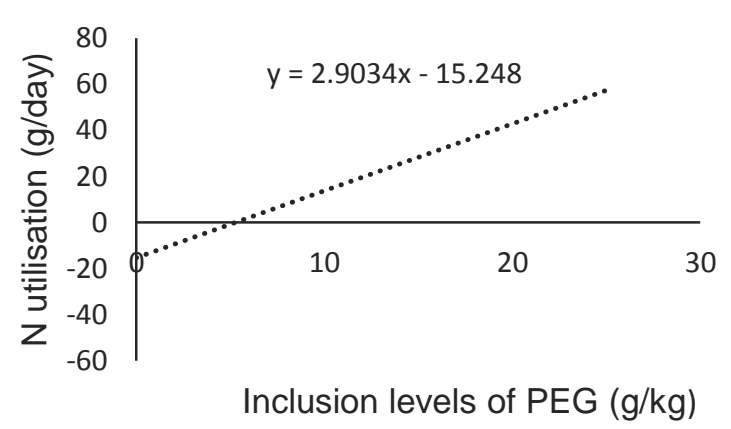

c)

Figure 2 Relationship between a) $\mathrm{N}$ intake; b) $\mathrm{N}$ retained; c) $\mathrm{N}$ utilisation; and d) urinary $\mathrm{N}$ excreted: faecal $\mathrm{N}$ excreted and polyethylene glycol inclusion level

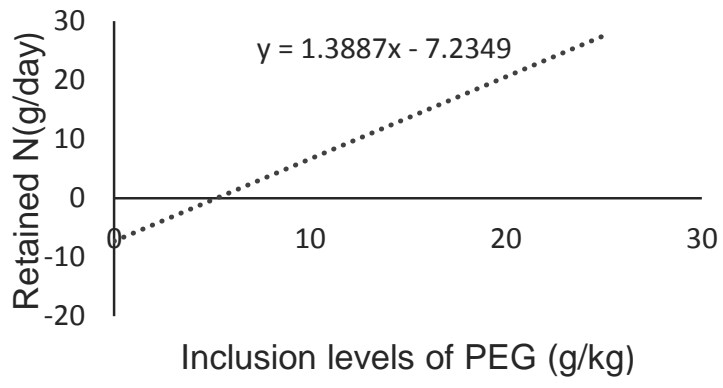

b)

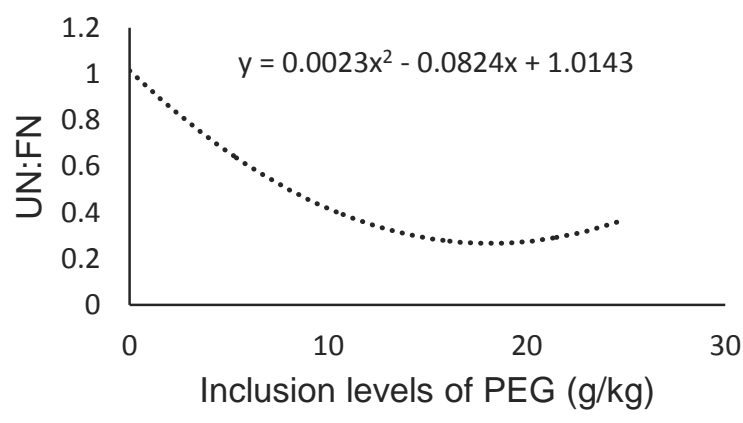

d) 


\section{Discussion}

The study tested the hypothesis that the inclusion of PEG 4000, a tannin-binding agent, inhibits the formation of tannin-protein complexes and improves the nutritive value of the feed (Bhat et al., 2013). The observed increase in BW as PEG inclusion level increased could be because PEG improves nutrient digestibility of $V$. tortilis leaf meal diets. The response of the pigs to PEG may show that PEG can eliminate deleterious effects of polyphenolic compounds in pig diets. The positive linear relationship between PEG inclusion and ADG suggest that, as more PEG was added to the diet, more tannins were neutralised. The negative effects of tannins on pig performance are reduced with increase in PEG inclusion level in tannin rich diets (Martens et al., 2013). The non-significant quadratic response of FCR to PEG-treated leaf meal could be associated with the ability of PEG to release protein from the tannin-protein complexes (Medugu et al., 2012). The FCR in this study could be explained by $\mathrm{N}$ retention.

Echeverria et al. (2002) reported that reduced nitrogen retention is a result of a reduction in crude protein digestibility and nitrogen utilization. Tanniferous diets are associated with formation of insoluble complexes with metal ions like iron and reduce their availability for absorption (Štukelj et al., 2010). Iron (Fe) is the vital component of the haemoglobin molecules that oxidise minerals inside and outside the body and is bound to transport and store proteins in the body. The observed quadratic response of Fe to PEG could be associated with prevention of tannin-protein complex by PEG. The tannin-protein complex is usually responsible for the low bioavailability of iron in tanniferous diets (Medugu et al., 2012). On the other hand, serum phosphorus, which is one of the important minerals that livestock require, and which affects protein synthesis, was not influenced statistically by the incorporation of PEG.

The response of nitrogen intake to PEG inclusion could be an indication of higher protein content being available for use by the pigs. This could be attributed to the positive effect of PEG on polyphenolic compounds in Vachellia, hence increase in feed intake and $\mathrm{N}$ intake (Bhat et al., 2013; Mlambo et al., 2015). The increase in intake could be explained by the reduced $\mathrm{N}$ loss through urinary excretion. The observed decreasing linear response of $\mathrm{N}$ excretion through urine to PEG could be associated with improved utilization of ingested N (Jetana et al., 2011). The PEG increases protein digestion by hindering the formation of the tannin-protein complex, and thus increases the digestibility of nitrogen fractions (Mlambo et al., 2015).

Reduced $\mathrm{N}$ excretion through urine and faeces indicates elimination of polyphenolic effects from $V$. tortilis leaf meal by PEG. Similar results were observed in goats fed Vachellia treated with different levels of PEG (Ben Salem et al., 2000). The observed reduction of $\mathrm{N}$ excretion through urine is similar with the findings made by Kang et al. (2012) who reported high $\mathrm{N}$ excretion through faeces in animals fed protein rich feeds. Nitrogen excretion through faeces is preferred to incretion through urine since nitrogen excreted via faeces is less harmful to the environment (Sommer et al., 2013). The nitrogen bound in faeces is less volatile due to the enzyme urease contained in faeces (Sommer et al., 2013).

The increased $N$ digestibility in PEG-treated $V$. tortilis leaf meal-based diet suggest the high affinity of tannins to PEG than proteins (Medugu et al., 2012). The PEG binds with tannins thereby preventing the formation of the tannin-protein complexes, and thus increases the digestibility of nitrogen. The same reason could explain the observed increase in N retained as PEG inclusion level increased. The increased linear relationship between $\mathrm{N}$ retained and PEG inclusion was expected. The PEG inclusion in Vachellia has been shown to reduce the negative effect of polyphenolic compounds on digestibility (Nsahlai et al., 2014). Improved nitrogen retention in small ruminants fed on Vachellia treated with PEG has also been reported (Ben Salem et al., 2000).

The observed quadratic response of $\mathrm{N}$ retained in percentage to $\mathrm{PEG}$ inclusion could be associated with the ability of PEG to bind tannins and release nutrients for digestion. An increase in $\mathrm{N}$ retention from PEG-treated Vachellia has been reported in sheep (Ben Salem et al., 2000). The increasing linear response in $\mathrm{N}$ utilization when pigs fed PEG treated $V$. tortilis leaf meal diet indicates benefits of PEG inclusion. The $N$ utilization could be explained by the response of $N$ intake, digestibility and retention of pigs fed into PEG treated $V$. tortilis leaf meal diet, in the current study. The observed improvement in $\mathrm{N}$ utilization with the inclusion of PEG is in agreement with literature (Ghandour et al., 2014; Mlambo et al., 2015; Hlatini et al., 2016). The increase in net protein utilization (NPU) and biological value (BV) with PEG inclusion level was expected. The response of NPU, a proportion of intake that is retained, could be associated to a high affinity of PEG for polyphenolic compounds, which improves the bioavailability of proteins (Bhat et al., 2013).

\section{Conclusion}

The inclusion of increasing levels of PEG in $V$. tortilis leaf meal-based diet showed a linear response to digestion, retention, utilization and excretion of nitrogen in urine and faeces, though quadratic response was observed only in $\mathrm{N}$ retention \% and $\mathrm{N}$ intake. The current study demonstrated that inclusion of PEG in $V$. tortilis leaf meal improves the utilization of ingested $\mathrm{N}$ and reduces most of the ammonia emission from urine. Therefore, the use of PEG to neutralize the negative effects of polyphenolic compounds could be 
recommended, as the increase $\mathrm{N}$ utilization and retention would represent lower $\mathrm{N}$ release to the environment.

\section{Acknowledgements}

Financial support was obtained from the Competitive Grant, University of KwaZulu-Natal. Authors also thank the National Research Foundation (96684) for financial assistance

\section{Authors' Contributions}

VAH executed the project, designed the study and conducted statistical analyses of the data, while TJZ assisted in statistical analyses and editing the draft. Lastly, MC conceived the research idea and edited the draft version of the manuscript.

\section{Conflict of Interest Declaration}

There authors declare no conflict of interest

\section{References}

Abdou, N., Nsahlai, I.V. \& Chimonyo, M. 2011. Effect of groundnut haulms supplementation on millet stover intake, digestibility and growth performance. Anim. Feed Sci. Tech. 169,176-184.

Association of Official Analytical Chemists (AOAC) 1990. Official methods of analysis. AOAC. 15th ed. Washington DC, USA.

Ben Salem, H., Nefzaoui, A., Ben Salem, L. \& Tisserand, L.J. 2000. Deactivation of condensed tannins in Acacia cyanophylla Lindl. foliage by polyethylene glycol in feed blocks: Effect on feed intake, diet digestibility, nitrogen balance, microbial synthesis and growth by sheep. Livest. Prod. Sci. 64,51-60.

Bhat, K.T., Kannan, A. \& Sharma, P.O. 2013. Value addition of feed and fodder by alleviating the antinutritional effects of tannins. Agric. Res. 2,189-206.

Echeverria, E., Belmar, R., Ly, J. \& Santos-Ricalde, H.R. 2002. Effect of Leucaena leucocepala leaf meal treated with acetic acid or sodium hydroxide on apparent digestibility and nitrogen retention in pig diet. Anim. Feed Sci. Tech. 101,151-159.

Ghandour, M.M., Fayed, A.M., Abdul-Aziz, G.M. \& Hanafy, M.A.2014. Effect of using polyethylene glycol or sodium bentonite on performance of sheep fed Acacia saligna. World App. Sci. J.32, 2309-2316.

Hlatini, V.A., Khanyile, M., Zindove, T.J. \& Chimonyo, M. 2016. Feed intake and growth performance of growing pigs fed on Acacia tortilis leaf meal treated with polyethylene glycol. Trop. Anim. Health Prod. 48, 585-91.

Jetana, T., Vongpipatana, C., Usawang, S. \& Thongruay, S. 2011. The use of tropical protein-rich leaves as supplements to Thai swamp buffalo receiving a basal diet of rice straw and treated leucaena (Leucaena leucocephala). Trop. Anim. Health Prod. 43, 57-67.

Kang, S., Wanapat, M., Pakdee, P., Pilajun, R. \& Cherdthong, A. 2012. Effects of energy level and Leucaena leucocephala leaf meal as a protein source on rumen fermentation efficiency and digestibility in swamp buffalo. Anim. Feed Sci. Tech. 174,131-139.

Khanyile, M., Ndou, S.P. \& Chimonyo, M. 2014. Influence of Acacia tortilis leaf meal-based diets on growth performance of pigs. Livest. Sci. 167, 211-218.

Lalthansanga, J. \& Samanta, A.K. 2011. Effect of feeding chayote (Sechium edule) meal on growth performance and nutrient utilization in indigenous pig (Zovawk) of Mizoram.. Vet. World 8, 918-923.

Lindberg, J.E. 2014. Fiber effects in nutrition and gut health in pigs. J. Anim. Sci. Biotechnol. 5, 15.

Martens, S.D., Tiemann, T.T., Bindelle, J., Peters, M. \& Lascano, C.E. 2013. Alternative plant protein sources for pigs and chickens in the tropics - nutritional value and constraints: A review. J. Agr. Rural Dev. Trop. 113, 101-123.

Medugu, C.I., Saleh, B., Igwebuike, J.U. \& Ndirmbita, R.L. 2012. Strategies to improve the utilization of tannin-rich feed materials by poultry. Int. J. Poult. Sci. 11, 417-423.

Mlambo, V., Marume, U. \& Gajana, C.S.2015. Review: Utility of the browser's behavioural and physiological strategies in coping with dietary tannins: Are exogenous tannin-inactivating treatments necessary? S. Afr. J. Anim. Sci. 45, 441-451.

National Research Council (NRC) 2012. Nutrient requirement of swine, 11th rev. ed. National Academy Press, Washington, DC, USA.

Nsahlai, I.V., Fon, F.N. \& Basha N.A.D. 2014. The effect of tannin with and without polyethylene glycol on in vitro gas production and microbial enzyme activity. S. Afr. J. Anim. Sci. 41, 337-344.

Ouellet, D. R., Petit, H. V., Veira, D. M. \& Charmley, E. 2004. Estimation of faecal output, digestibility, and intake using a controlled release capsule of alkanes in early and late lactation dairy cows fed two levels of concentrate. Can. J. Anim. Sci. 84, 277-289.

Patráš, P., Nitrayová, S., BreSteNSký, M. \& Heger, J. 2014. The effects of benzoic acid and protein level on urine ph and ammonia emission of pigs. Slovak J. Anim. Sci. 47, 100-104.

Reed, J.D.1986. Relationships among soluble phenolics, insoluble proancthocyanidins and fiber in East African browse species. J. Range Manage. 39, 5-7.

SAS (Statistical Analysis Systems) 2008. SAS User's guide: Statistics, version9.2. SAS Institute, Cary, NC, USA

Sommer, S.G., Christensen, M.L., Schmidt, T. \& Jensen, L.S. 2013. Animal manure recycling: Treatment and management. John Wiley \& Sons. 
Štukelj, M., Valenčak, Z., Krsnik, M. \& Svete, A.N. 2010. The effect of the combination of acids and tannins in diet on the performance and selected biochemical, haematological and antioxidant enzyme parameters in grower pigs. Acta Vet. Scand. 52, 19.

Van Soest, P.J., Robertson, J.B. \& Lewis, B.A. 1991. Methods for dietary fiber, neutral detergent fiber, and non-starch polysaccharides in relation to animal nutrition. J. Dairy Sci. 74, 3583-3597.

Whittemore, E.C., Emmans, G.C. \& Kyriazakis, I. 2003. The relationship between live weight and intake of bulky foods in pigs. J. Anim. Sci. 76, 89-100.

Woyengo, T.A., Beltranena, E. \& Zijlstra R.T. 2014. Non-ruminant nutrition symposium: Controlling feed cost by including alternative ingredients into pig diets: A review. J. Anim. Sci. 92, 1293-305. 